\title{
Characterization of three-phase partitioned exo-polygalacturonase from Aspergillus sojae with unique properties
}

\author{
Nergiz Dogan ${ }^{\mathrm{a}}$, Canan Tari ${ }^{\mathrm{b}, *}$ \\ ${ }^{a}$ Biotechnology and Bioengineering Programme, Izmir Institute of Technology, Izmir, Turkey \\ ${ }^{\mathrm{b}}$ Department of Food Engineering, Izmir Institute of Technology, Gulbahce Campus, Urla, 35437 Izmir, Turkey
}

Received 17 January 2007; received in revised form 6 August 2007; accepted 15 August 2007

\begin{abstract}
Exo-polygalacturonase enzyme produced by Aspergillus sojae ATCC 20235 was purified using three-phase partitioning (TPP), an emerging bio-separation technique where a single step as compared to the classical multi-step purification was used. Using this technique, crude enzyme solution ( $\mathrm{pH}$ 6.6) saturated to $30 \%(\mathrm{w} / \mathrm{v})$ with ammonium sulphate and with a crude extract to tert-butanol ratio of $1: 1(\mathrm{v} / \mathrm{v})$ at $25{ }^{\circ} \mathrm{C}$ resulted in $25.5 \%$ recovery of exo-polygalacturonase with a 6.7 -fold purification. The purified enzyme was characterized with respect to its activity and stability at various $\mathrm{pH}$ and temperature ranges. Optimum $\mathrm{pH}$ and temperature for maximum activity were determined as $\mathrm{pH} 4$ and $55^{\circ} \mathrm{C}$. The enzyme was stable at both acidic and alkaline $\mathrm{pH}$ for $2 \mathrm{~h}$ at $30^{\circ} \mathrm{C}$. The thermal stability study showed that the purified enzyme had an inactivation energy of $68.41 \mathrm{kcal} / \mathrm{mol}$ and a half-life $\left(t_{1 / 2}\right)$ value of $3.6 \mathrm{~h}$ at $75^{\circ} \mathrm{C}$ presenting a large thermal stability. The kinetic constants $K_{\mathrm{m}}$ and $V_{\text {max }}$ using polygalacturonic acid as substrate were $0.75 \mathrm{~g}^{-1}$ and $1.14 \mu \mathrm{mol} \mathrm{min}{ }^{-1}$, respectively. SDS-PAGE profiling revealed that the purified exopolygalacturonase had two bands with the molecular weights of 36 and $53 \mathrm{kDa}$. The enzyme was completely inhibited in the presence of Mn ${ }^{2+}$ and SDS and induced significantly by EDTA, glycerol and $\beta$-mercaptoethanol.
\end{abstract}

(C) 2007 Elsevier B.V. All rights reserved.

Keywords: Exo-polygalacturonase; Three-phase partitioning; Aspergillus sojae; Microbial enzymes; Enzyme characterization

\section{Introduction}

Microbial pectolytic enzymes of fungal origin are of great importance with tremendous potentials to offer to the industry. Among these applications are retting of flax and vegetable fibres, increasing the yield of fruit juice extraction, de-pectinisation and clarification of fruit juices, extraction of oils from vegetables and citrus peels, pre-treatment of pectic waste water, fermentation of coffee and tea, manufacturing of paper and pulp, production of poultry feed and purification of plant viruses $[1,2]$. It is reported that pectinases hold a share of $25 \%$ in the global sales of food enzymes where this value is expected to increase over time with the invention of new application areas [3]. Pectolytic enzymes are classified mainly into two main groups of de-esterification and depolymerising enzymes based on their degradation mechanism [1,4,5]. The enzymes depolymerising polygalacturonic acid are further classified

\footnotetext{
* Corresponding author. Tel.: +90 232 7506316; fax: +90 2327506196. E-mail address: ctari7@yahoo.com (C. Tari).
}

into polygalacturonase simply hydrolyzing the $\alpha$-1,4-linkage and polygalacturonate lyase cleaving trans-eliminatively. Both include exo-type enzymes, which catalyze the release of single galacturonic acid residue from the non-reducing end and random fashion endo-type hydrolyzing enzymes which release oligosaccharidic chains of various lengths [1].

Since applications of pectinases in various fields are broadening, it is important to discover new strains producing pectinases with novel properties and understand the nature and properties of these enzymes for their efficient and effective usage. With this perspective exo-polygalacturonase which attracts the most attention due to its wide use among pectinases is produced in this study by Aspergillus sojae ATCC 20235 (not considered for this purpose so far) and purified by three-phase partitioning (TPP) for a one-step purification based on a modified procedure reported by Sharma and Gupta [6]. In this process (TTP) the protein extract is mixed with ammonium sulphate and tertbutanol. Three phases are formed within short periods of time (about $1 \mathrm{~h}$ ): lower aqueous layer, interfacial protein precipitate and upper tert-butanol layer [7]. This technique is an emerging bio-separation technique, which employs collective operation of 
principles involved in numerous techniques such as conventional salting out, cosolvent, isoionic, osmolytic and kosmotropic precipitation of proteins [8].

The purified enzyme was further characterized with respect to its activity and stability at various $\mathrm{pH}$ and temperature ranges. SDS-PAGE profiling and determination of its $K_{\mathrm{m}}$ and $V_{\max }$ parameters together with its thermal inactivation kinetics was carried out. The effect of metal ions and certain compounds such as EDTA, glycerol, Tween 80, SDS and $\beta$-mercaptoethanol were also investigated. To date there is no literature report on the purification and characterization of this enzyme using this organism. This paper will be one of the initial studies in this field. In our previous work [9-11] we reported that this organism holds a great potential for the production of this enzyme in submerged and solid state fermentation. Therefore in order to exploit new industrial potentials of exo-polygalacturonase it is necessary to investigate new microbial strains and understand the structure-stability relationship of this enzyme. Separation and purification of proteins/enzymes, which account for a major fraction of the overall production cost, in an efficient way and maintaining the desired level of enzyme activity over a long period of time and improving its stability are important parameters for the selection and design of pectinases [5,8]. The knowledge gained in this way will offer new possibilities in improving the potential and effective use of this enzyme in such diverse and broad areas.

\section{Materials and methods}

\subsection{Microorganism and development of inoculum}

A. sojae ATCC 20235 was purchased in the lyophilized form, from Promochem Inc., an international distributor of ATCC (American Type of Culture Collection) in Europe. YME agar slant medium containing, malt extract $(10 \mathrm{~g} / \mathrm{l})$, yeast extract ( $4 \mathrm{~g} / \mathrm{l})$, glucose ( $4 \mathrm{~g} / \mathrm{l})$ and agar $(20 \mathrm{~g} / \mathrm{l})$ was used for the propagation of this culture and incubated at $30^{\circ} \mathrm{C}$ until well sporulation. Stock cultures of these strains were prepared with $20 \%$ glycerol water and stored at $-80^{\circ} \mathrm{C}$.

The spore suspensions used as inoculum were obtained on molasses agar slants containing glycerol $(45 \mathrm{~g} / \mathrm{l})$, peptone (18 g/l), molasses (45 g/l), $\mathrm{NaCl}(5 \mathrm{~g} / \mathrm{l}), \mathrm{FeSO}_{4} \cdot 7 \mathrm{H}_{2} \mathrm{O}(15 \mathrm{mg} / \mathrm{l})$, $\mathrm{KH}_{2} \mathrm{PO}_{4}(60 \mathrm{mg} / \mathrm{l}), \mathrm{MgSO}_{4}(50 \mathrm{mg} / \mathrm{l}), \mathrm{CuSO}_{4} \cdot 5 \mathrm{H}_{2} \mathrm{O}(12 \mathrm{mg} / \mathrm{l})$, $\mathrm{MnSO}_{4} \cdot \mathrm{H}_{2} \mathrm{O}(15 \mathrm{mg} / \mathrm{l})$ and agar $(20 \mathrm{~g} / \mathrm{l})$, after the pre-activation step performed on YME agar using the stock cultures. The incubation temperature and time for each of the steps were $30^{\circ} \mathrm{C}$ and 1 week, respectively. The harvesting of the spores from the slants was done using $5 \mathrm{ml}$ of Tween 80 -water $(0.02 \%)$. The spore suspension was collected in sterile falcon tube and stored at $4{ }^{\circ} \mathrm{C}$ until the actual study. The initial spore counts and viability counts were recorded.

\subsection{Production of exo-polygalacturonase}

The cultivation was carried in a solution containing glucose $(25 \mathrm{~g} / \mathrm{l})$, peptone $(2.5 \mathrm{~g} / \mathrm{l})$, disodium phosphate $(3.2 \mathrm{~g} / \mathrm{l})$, monosodium phosphate $(3.3 \mathrm{~g} / \mathrm{l})$, maltrin $(120 \mathrm{~g} / \mathrm{l})$ and corn steep liquor $(4 \mathrm{~g} / \mathrm{l})$. The fermentation was conducted at $350 \mathrm{rpm}$ at $30{ }^{\circ} \mathrm{C}$ for $96 \mathrm{~h}$. After $96 \mathrm{~h}$ of incubation, each flask was assayed for enzyme activity and protein determination. Crude enzyme activity was determined on supernatant obtained after the centrifugation of the broth at $5000 \mathrm{rpm}$ for $15 \mathrm{~min}$.

\subsection{Three-phase partitioning of the exo-polygalacturonase}

Purification of the exo-polygalacturonase enzyme was performed by three-phase partitioning for a one-step purification step based on a modified procedure reported by Sharma and Gupta [6]. In order to adopt the mentioned procedure to our study, the crude enzyme solution $(20.4 \mathrm{U} / \mathrm{ml}$ at $\mathrm{pH} 6.6)$ was brought to 25,30 and $40 \%$ (w/v) saturations using ammonium sulphate (Table 1). To this solution, tert-butanol was added in order to obtain $1: 1$ or $1: 2(\mathrm{v} / \mathrm{v})$ ratio of crude enzyme to tertbutanol at the specified temperature (Table 1). After incubation for $1 \mathrm{~h}$ at 25 or $37^{\circ} \mathrm{C}$, the mixture was centrifuged $(2000 \times g$ for $5 \mathrm{~min}$ ) to facilitate separation of phases. The lower aqueous layer and the interfacial precipitate were collected; the latter was dissolved in $0.1 \mathrm{M}$ sodium phosphate buffer, $\mathrm{pH}$ 6.6. The best conditions which resulted into maximum recovery were used as standard purification procedure. The purified enzyme obtained under these conditions was used for further characterization. The activity of the crude extract $(20.4 \mathrm{U} / \mathrm{ml})$ initially added was taken as $100 \%$. The time of treatment (incubation time) was not considered as factor variable since in a preliminary study it was determined that $1-2 \mathrm{~h}$ did not cause a significant increase, hence $1 \mathrm{~h}$ was applied.

\subsection{Enzyme assay}

Exo-polygalacturonase activity was assayed according to the procedure given by Panda et al. [12] by using polygalacturonic acid as substrate at $\mathrm{pH} 6.6$ and $26^{\circ} \mathrm{C}$. In this study, one unit of enzyme activity was defined as the amount of enzyme that catalyses the release of $1 \mu \mathrm{mol}$ of galacturonic acid per unit volume of culture filtrate per unit time at standard assay conditions. Galacturonic acid (Sigma, St. Louis, MO) was used as standard for the calibration curve of exo-polygalacturonase activity.

\subsection{Protein determination}

The total protein content of the samples were determined according to the method described by Lowry et al. [13]; the protein standard used was bovine serum albumine.

\subsection{SDS-PAGE profiling}

SDS-PAGE was done according to the procedure reported by Laemmli [14] using 10\% resolving and 5\% stacking gel. Protein bands were visualized after staining with Coomassie brilliant blue R250 for $1 \mathrm{~h}$ and de staining using methanol-water containing $10 \%$ acetic acid for $2-3 \mathrm{~h}$. The molecular weight of the protein bands were identified using Gel Documentation System 
Table 1

Various conditions used for three-phase partitioning (TPP) of the exo-polygalacturonase enzyme

\begin{tabular}{|c|c|c|c|c|c|}
\hline Condition & Temperature $\left({ }^{\circ} \mathrm{C}\right)$ & $\begin{array}{l}\text { Percent saturation with } \\
\text { ammonium sulphate }(\mathrm{w} / \mathrm{v})\end{array}$ & $\begin{array}{l}\text { Enzyme:tert-butanol } \\
\text { ratio }(\mathrm{v} / \mathrm{v})\end{array}$ & Degree of purification & Activity recovery (\%) \\
\hline 1 & 25 & 25 & $1: 1$ & 1.1 & $12.7 \pm 2.4$ \\
\hline 2 & 25 & 25 & $1: 2$ & 0.5 & $7.4 \pm 5.9$ \\
\hline 4 & 25 & 30 & $1: 2$ & 1.5 & $7.8 \pm 3.2$ \\
\hline 5 & 25 & 40 & $1: 1$ & 1.7 & $10.3 \pm 3.3$ \\
\hline 6 & 25 & 40 & $1: 2$ & 3.4 & $17.2 \pm 1.3$ \\
\hline 9 & 37 & 30 & $1: 1$ & 0.7 & $8.8 \pm 1.4$ \\
\hline 10 & 37 & 30 & $1: 2$ & 1.2 & $9.8 \pm 1.4$ \\
\hline 11 & 37 & 40 & $1: 1$ & 2.8 & $21.6 \pm 4.7$ \\
\hline 12 & 37 & 40 & $1: 2$ & 1.5 & $9.8 \pm 1.5$ \\
\hline
\end{tabular}

TPP was carried out after the $\mathrm{pH}$ of the exo-polygalacturonase enzyme preparation had been adjusted to 6.6 . The starting volume of the enzyme was $2 \mathrm{ml}$ under each condition.

(CN-3000 WL) and the associated software Bio-1D++, Vilber Lourmat (France).

\subsection{Effect of $\mathrm{pH}$ on activity and stability of the purified exo-polygalacturonase}

The effect of $\mathrm{pH}$ on the activity of the purified exopolygalacturonase was determined by assaying the enzyme activity at different $\mathrm{pH}$ values ranging from 3.0 to 12.0 using $0.1 \mathrm{M}$ of the following buffer systems: acetate (3.0, 4.0, and 5.0), phosphate ( $\mathrm{pH} 6.0$ and 7.0), tris- $\mathrm{HCl}(\mathrm{pH} \mathrm{8.0,9.0,} \mathrm{and} \mathrm{10.0)} \mathrm{and}$ $\mathrm{Na}_{2} \mathrm{HPO}_{4}-\mathrm{NaOH}$ (pH 11.0 and 12.0) buffer systems [15]. The relative activities were based on the ratio of the activity obtained at certain $\mathrm{pH}$ to the maximum activity obtained at that range and expressed as percentage.

The $\mathrm{pH}$ stability of $A$. sojae exo-polygalacturonase was investigated in the $\mathrm{pH}$ range of $3.0-12.0$. Therefore, $1 \mathrm{ml}$ of the crude enzyme was mixed with $1 \mathrm{ml}$ of the buffer solutions mentioned above and incubated at $30^{\circ} \mathrm{C}$ for $2 \mathrm{~h}$. Afterwards aliquots of the mixtures were taken to measure the residual exopolygalacturonase activity (\%) with respect to control, under standard assay conditions.

\subsection{Effect of temperature on activity and stability}

The effect of temperature on the activity of the purified exopolygalacturonase was determined by performing the standard assay procedure at different temperatures ranging from 25 to $75^{\circ} \mathrm{C}\left(25,37,45,55,65\right.$, and $\left.75^{\circ} \mathrm{C}\right)$. Before the addition of enzymes, the substrate $(0.24 \%(\mathrm{w} / \mathrm{v})$ polygalacturonic acid) was preincubated at the respective temperature for $10 \mathrm{~min}$. The relative activities (as percentages) were expressed as the ratio of the purified exo-polygalacturonase activity obtained at certain temperature to the maximum activity obtained at the given temperature range.

The thermostability of the purified exo-polygalacturonase was investigated by measuring the residual activity after incubating the enzyme at various temperatures ranging from 25 to $65^{\circ} \mathrm{C}\left(25,37,45,55\right.$ and $\left.65^{\circ} \mathrm{C}\right)$ for $10,20,30$ and $60 \mathrm{~min}$.

\subsection{Kinetics of thermal inactivation and estimation of the inactivation energy}

Thermal inactivation kinetics of the purified exopolygalacturonase was studied by incubating the enzyme at different temperatures $\left(75,80,82.5\right.$ and $\left.85^{\circ} \mathrm{C}\right)$ in the absence of the substrate. Aliquots were withdrawn at periodic intervals and cooled in an ice bath prior to assay as described above. The residual activity was expressed as $\%$ of the initial activity. From a semilogarithmic plot of residual activity versus time, the inactivation rate constants $\left(k_{\mathrm{d}}\right)$ were calculated (from slopes), and apparent half-lives were estimated using Eq. (1). The half-life is known as the time where the residual activity reaches $50 \%$.

$t_{1 / 2}=\frac{\ln 2}{k_{\mathrm{d}}}$

The temperature dependence of $k_{\mathrm{d}}$ was analyzed using the Arrhenius plot [16]. The inactivation energy was calculated from the Arrhenius equation as

$\ln \left(k_{\mathrm{d}}\right)=\ln \left(k_{0}\right)-\left(\frac{E_{\mathrm{d}}}{R}\right) \frac{1}{T}$

The values of $E_{\mathrm{d}}$ and $k_{0}$ were estimated from the slope and intercept of the plot of $\ln \left(k_{\mathrm{d}}\right)$ versus $1 / T$, respectively. ( $R$ is the ideal gas constant $=1.987 \mathrm{cal} \mathrm{mol}^{-1} \mathrm{~K}^{-1}$ ).

\subsection{Determination of kinetic constant}

The kinetic constants $\left(V_{\max }\right.$ and $\left.K_{\mathrm{m}}\right)$ were determined using Lineweaver-Burk double reciprocal (1/v versus $1 / S)$ plot [16], where different concentrations of polygalacturonic acid were used as substrate $(0.1-1 \mathrm{mg} / \mathrm{ml})$ at $\mathrm{pH} 6.6$ and $26^{\circ} \mathrm{C}$.

$\frac{1}{v}=\frac{1}{V_{\mathrm{m}}}+\frac{K_{\mathrm{m}}}{V_{\mathrm{m}}} \frac{1}{S}$

With a slope of $K_{\mathrm{m}} / V_{\mathrm{m}}$ and intercept of $1 / V_{\mathrm{m}}$ (Eq. (3)) estimated $K_{\mathrm{m}}$ and $V_{\mathrm{m}}$ values were determined. 
All the analytical grade materials and the culture media ingredients were obtained from Sigma-Aldrich.

\subsection{Effect of metal ions and various compounds on the exo-polygalacturonase activity}

Metal ions $\left(\mathrm{K}^{+}, \mathrm{Na}^{+}, \mathrm{Ca}^{2+}, \mathrm{Mg}^{2+}, \mathrm{Mn}^{2+}, \mathrm{Zn}^{2+}, \mathrm{Cu}^{2+}\right.$ and $\mathrm{Fe}^{2+}$ ) and various compounds (EDTA, glycerol, Tween 80, SDS and $\beta$-mercaptoethanol) were tested for their effect on purified exo-polygalacturonase activity in Na-phosphate buffer, $\mathrm{pH}$ 6.6. The enzyme was preincubated for $30 \mathrm{~min}$ at $37^{\circ} \mathrm{C}$ with $1 \mathrm{mM}$, $5 \mathrm{mM}$ and $10 \mathrm{mM}$ of listed ions and compounds (Tables 3 and 4) as a final concentration prior to the substrate addition. Activity without added metal ions and compounds was taken as $100 \%$ activity. Each value represents the average of two experiments. The confidence limit used in all experiments was $95 \%$.

\section{Results and discussion}

\subsection{Three-phase partitioning of the exo-polygalacturonase}

In order to adapt the procedure developed by Sharma and Gupta [6], to our study, various experiments at different percent saturations of ammonium sulphate, different crude extract to tert-butanol (v/v) ratio and different temperatures as given in Table 1 were performed. In all the experiments the starting protein concentration (containing $20.4 \mathrm{U} \mathrm{ml}^{-1}$ of exopolygalacturonase activity) was $15.6 \mathrm{mg} \mathrm{ml}^{-1}$. The effect of these parameters on the yield and on the degree of purification is presented in Table 1. As it is seen all these three parameters have major influence on the purification of the exo-polygalacturonase. For example an increase of the saturation level of ammonium sulphate from 25 to $30 \%$, at 1:1 crude extract to tert-butanol (v/v) ratio and $25^{\circ} \mathrm{C}$, increased the recovery by 2 and purification by 6.1-fold, however, further increase to $40 \%$ saturation decreased the same responses by 2.5 and 3.9, respectively. Similarly, an increase of the temperature from 25 to $37^{\circ} \mathrm{C}$ at $30 \%$ saturation of ammonium sulphate and 1:1 crude extract to tert-butanol (v/v) ratio caused 2.89- and 9.57-fold of reduction in recovery yield and purification, respectively. The effect of the crude extract to tert-butanol $(\mathrm{v} / \mathrm{v})$ ratio was also very considerable where the change from 1:1 to $1: 2$ crude extract to tert-butanol $(\mathrm{v} / \mathrm{v})$ ratio, decreased the responses (recovery and degree of purification) by 3.26 and 4.47 , respectively. Based on these observations the best results were obtained at $30 \%$ saturation with ammonium sulphate, 1:1 (v/v) ratio of crude extract to tert-butanol and $25^{\circ} \mathrm{C}$ where, 6.7 -fold purification and $25.5 \%$ recovery was observed. The purified enzyme in the forthcoming characterization experiments was obtained by this adapted procedure. These conditions were in good correlation with various applications of TPP on different proteins, enzymes and soybean oil [17-20]. It is reported that working with high concentrated protein solutions often leads to loss of yields, where poor results are obtained beyond $10 \mathrm{mg} \mathrm{ml}^{-1}$ of the starting protein concentration [20,21]. Therefore this might be one of the reasons in this study for the low recovery yield $(25.5 \%)$. It is recommended in future studies to start with lower protein concentrations. However, the

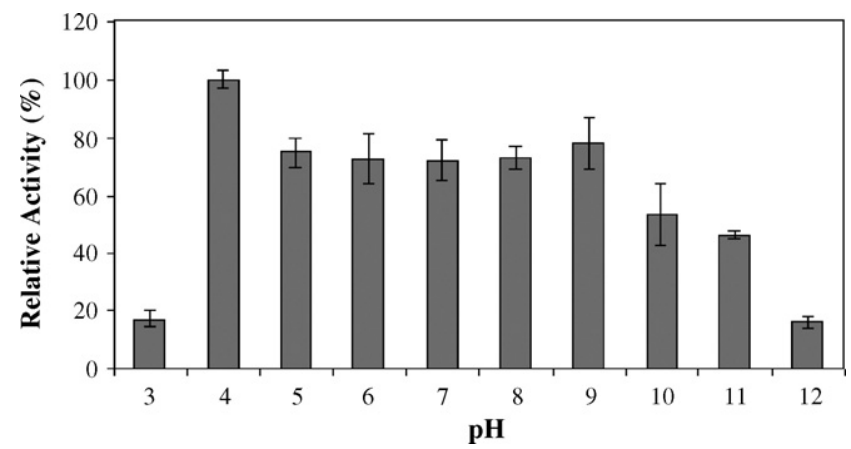

Fig. 1. Effect of $\mathrm{pH}$ on the activity of the purified exo-polygalacturonase enzyme. Each experiment was carried out three times, the difference in individual readings in each set of corresponding experiments was less than $10.5 \%$.

degree of purification of exo-polygalacturonase obtained in this study was $1.68,3.52$ and 5.73 times higher than the studies conducted by Keon and Waksman, Riou et al. and Sakamoto et al., respectively, where ammonium sulphate precipitation was used alone [22-24]. In those studies ammonium sulphate precipitation serves as an intermediate step prior to other chromatographic steps used in the purification, however, here a pure enzyme not requiring any other treatment is obtained in a single step. Therefore this treatment is economically more feasible and relatively simple. Besides when the degree of purification was compared to various studies where TPP was employed, the current results were relatively above those $[7,8,21,25]$. It was concluded that this modified procedure could be recommended as a single purification step of exo-polygalacturonases of similar organisms and holds a potential to be applicable to industrial scales.

\subsection{Effect of pH on exo-polygalacturonase activity and stability}

The effect of $\mathrm{pH}$ on the exo-polygalacturonase activity is presented in Fig. 1. As it can be observed, the enzyme was active over a broad $\mathrm{pH}$ range, displaying over $71 \%$ of its activity in the $\mathrm{pH}$ range of 4.0-9.0 with an optimum $\mathrm{pH}$ of 4 . A slight increase to $78 \%$ relative activity was observed at $\mathrm{pH} 9$. A further distance from these $\mathrm{pH}$ values decreased the relative activity down to $17 \%$. These findings were in correlation with several earlier reports showing $\mathrm{pH}$ optima of 4.8 for exo-polygalacturonase from A. niger and pH optima of 5.0 for Rhizopus stolonifer [5]. Similarly, the polygalactururonase of S. thermophile Apinis was reported to be active over a wide $\mathrm{pH}$ range (3.0-9.0) as well [26]. Among the polygalacturonases obtained from different microbial sources, most have the optimal $\mathrm{pH}$ ranges of 3.5-5.5 [3]. The high relative activity in the alkali $\mathrm{pH}$ region in addition to the acidic $\mathrm{pH}$ optima, will open up new application windows for the current purified exo-polygalacturonase unlike other exopolygalacturonases which are mostly known to have narrow $\mathrm{pH}$ ranges [3].

Investigations on $\mathrm{pH}$ stability by incubating the enzyme in suitable buffer systems for $2 \mathrm{~h}$ at $30^{\circ} \mathrm{C}$ (Fig. 2) revealed, that the exo-polygalacturonase enzyme was very stable at the broad $\mathrm{pH}$ range of $\mathrm{pH} 4-9$, retaining more than $73 \%$ of its activity. At 


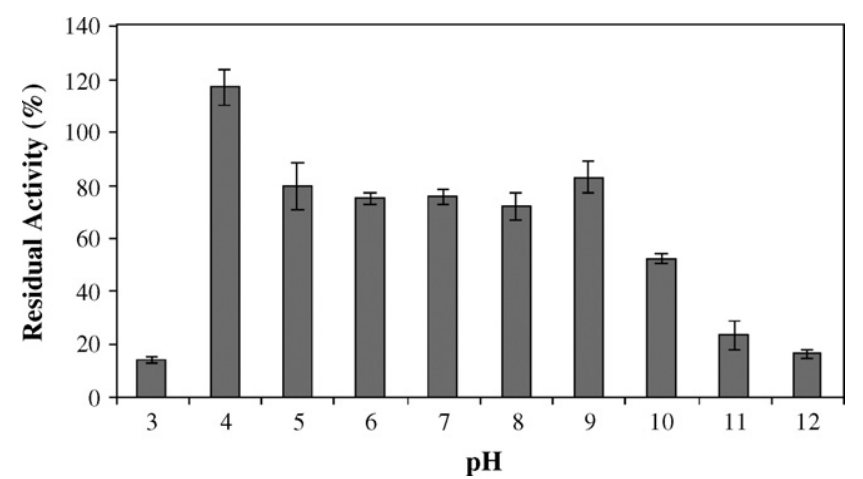

Fig. 2. Effect of $\mathrm{pH}$ on the stability of the purified exo-polygalacturonase enzyme. Each experiment was carried out three times, the difference in individual readings in each set of corresponding experiments was less than $8.7 \%$.

its optimum $\mathrm{pH}$ of 4 the residual activity was $17.5 \%$ higher than the control. However, the stability was significantly reduced to $52-16 \%$ between $\mathrm{pH} 10$ and 12 . It is reported that the inactivation process is found to be faster at high alkaline $\mathrm{pHs}$ due to disulfide exchange, which usually occurs at near neutral and alkaline conditions.

Therefore, exo-polygalacturonase like the one characterized in this study can be a potential candidate for different applications in the industry demanding either acidic or alkaline $\mathrm{pH}$ ranges. In addition, with the broad $\mathrm{pH}$ stability range, this enzyme can be considered suitable for applications requiring long exposure times. Hence, enhancing the stability and maintaining the desired level of activity over long period of time are two significant points which are taken into account for the selection of enzymes in industrial applications.

\subsection{Effect of temperature on exo-polygalacturonase activity and stability}

The A. sojae exo-polygalacturonase was active over a broad temperature range of $25-75{ }^{\circ} \mathrm{C}$ with an optimum temperature of $55^{\circ} \mathrm{C}$ (Fig. 3). It retained more than $66 \%$ of its activity at 65 and $75^{\circ} \mathrm{C}$. This optimum temperature was in agreement with the studies conducted by several authors using different strains. For example Sakamoto et al. [22], found the optimum temperature

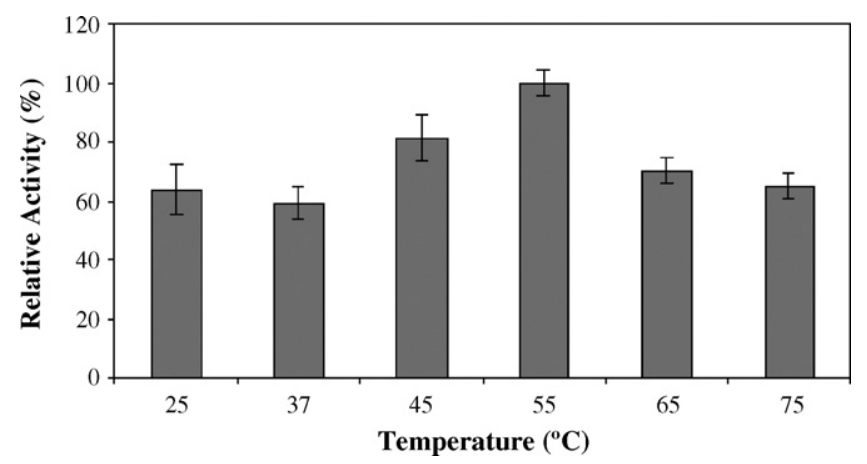

Fig. 3. Effect of temperature on the activity of the purified exopolygalacturonase enzyme. Each experiment was carried out three times, the difference in individual readings in each set of corresponding experiments was less than $8.2 \%$.

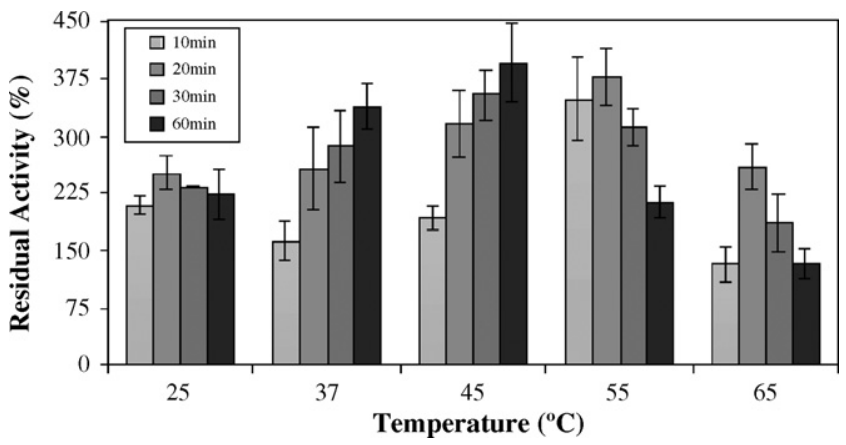

Fig. 4. Effect of temperature on the stability of the purified exopolygalacturonase enzyme. Each experiment was carried out two times, the difference in individual readings in each set of corresponding experiments was less than $15 \%$.

of an exo-polygalacturonase from A. niger as $60^{\circ} \mathrm{C}$, similarly, maximum activity for commercial enzyme, Rapidase C80 was determined at $55^{\circ} \mathrm{C}$ [27]. Furthermore, the partially purified polygalacturonase from Sporotrichum thermophile Apinis was optimally active at $55^{\circ} \mathrm{C}$ as well $[3,4]$.

Thermostability is the ability of enzyme to resist against thermal unfolding in the absence of substrates [28]. The thermostability of the purified exo-polygalacturonase was determined by measuring the residual activity of the enzyme after incubation at various temperatures ranging from 25 to $65^{\circ} \mathrm{C}$ for 10, 20, 30 and $60 \mathrm{~min}$. As it is shown in Fig. 4, the increase in temperature and time caused an overall increase in the stability until $55^{\circ} \mathrm{C}$ and $20 \mathrm{~min}$ after which a decline was observed. The maximum residual activity of $397 \%$ was observed at $45^{\circ} \mathrm{C}$ and $60 \mathrm{~min}$. The enzyme was very thermostable even at $65^{\circ} \mathrm{C}$ incubated for $60 \mathrm{~min}$, it possessed $133 \%$ of residual activity. This clearly demonstrated that the enzyme was induced with the temperature increase and especially at its optimum temperature of $55^{\circ} \mathrm{C}$ incubated for $20 \mathrm{~min}$ it was stable and exhibit $379 \%$ of residual activity. This is an important finding pointing out that in various applications carried out at this temperature the total enzyme amount required will be reduced significantly which will be reflected eventually in the economics of the process. In order to increase productivity and reduce microbial contaminations, industrial processes may require reactions carried out at high temperatures. That is why thermostable enzymes have been the target of many studies involving the elucidation of thermal inactivation mechanism and development of strategies for stability enhancement [27]. Therefore, the current exo-polygalacturonase in this study will exhibit a new example for thermostable enzymes obtained from a new source (A. sojae) with unique properties.

After the use of exo-polygalacturonases in the industry it is important to remove or inactivate them, where the estimation of thermal inactivation comes in to the picture discussed below.

\subsection{Kinetics of thermal inactivation and estimation of the inactivation energy}

Enzyme inactivation is one of major constrains in biotechnological processes therefore it is important to understand the 
Table 2

Kinetic parameters for thermal inactivation of the purified exopolygalacturonase enzyme

\begin{tabular}{llc}
\hline$T\left({ }^{\circ} \mathrm{C}\right)$ & $k_{\mathrm{d}}\left(\mathrm{min}^{-1}\right)$ & $t_{1 / 2}(\mathrm{~min})$ \\
\hline 75 & 0.0032 & 216.609 \\
80 & 0.0285 & 24.321 \\
82.5 & 0.0350 & 19.801 \\
85 & 0.0492 & 14.088
\end{tabular}

From slope of the semilogaritmic plot of residual activity vs. time for each temperature, the inactivation rate constants $\left(k_{\mathrm{d}}\right)$ were calculated. $\left(R^{2}=0.98\right.$ for $85^{\circ} \mathrm{C}, R^{2}=0.93$ for $82.5^{\circ} \mathrm{C}, R^{2}=0.95$ for $80^{\circ} \mathrm{C}$ and $R^{2}=0.72$ for $75^{\circ} \mathrm{C}$ )

mechanism of inactivation. Inactivation is defined as a process where the secondary, tertiary or quaternary structure of a protein changes without breaking covalent bonds. The inactivation of pectolytic enzymes is assumed to follow first order kinetics [29]. Inactivation rate constants $\left(k_{\mathrm{d}}\right)$ of exo-polygalacturonase which are presented in Table 2 (at $75,80,82.5$ and $85^{\circ} \mathrm{C}$ ) were calculated from the slope of semilogarithmic plot of residual activity versus time. Similarly the half-life values estimated using these constants and Eq. (1), are presented in the same Table. The half-life of exo-polygalacturonase at $75^{\circ} \mathrm{C}$ was 8.9 , 10.96 and 15.36 times higher than the half-life values at temperatures of $80,82.5$ and $85^{\circ} \mathrm{C}$, respectively at $\mathrm{pH}$ 6.6. This issue once again reveals the thermal stability of this enzyme at $75^{\circ} \mathrm{C}$ and its easy inactivation at higher temperatures such as 80 and $85^{\circ} \mathrm{C}$.

Inactivation energy of purified exo-polygalacturonase was determined as $E_{\mathrm{d}}=68.41 \mathrm{kcal} \mathrm{mol}^{-1}$ from the slopes of the linear curve plotted by $1 / T$ versus $\ln k_{\mathrm{d}}$ using Eq. (2). This value is in the range of the values (40-70 $\left.\mathrm{kcal} \mathrm{mol}^{-1}\right)$ estimated for many microbial enzymes [16]. The inactivation energy estimated for this enzyme was 1.96, 1.71 and 1.77 times higher than the commercial exo-polygalacturonases like Rapidase C80, Pectinase CCM and Pectinex 3XL, respectively, compared to a study conducted by Ortega et al. [27]. These close approximations with the current commercial enzymes indicated that the purified enzyme could be a good candidate for various industrial applications.

\subsection{Calculation of kinetic constants}

The kinetic parameters of $A$. sojae exo-polygalacturonase for hydrolysis toward polygalacturonic acid (PGA) at pH 6.6 and $26^{\circ} \mathrm{C}$ were obtained by a typical double reciprocal Lineweaver Burk plot (Eq. (3)). The $K_{\mathrm{m}}$ and $V_{\mathrm{m}}$ values for hydrolyzing PGA were $0.751 \mathrm{~g} / \mathrm{l}$ and $1.139 \mu \mathrm{mol} / \mathrm{min}$, respectively. The estimated $K_{\mathrm{m}}$ value which indicates the affinity of the enzyme towards the substrate is 1.79 and 2.13 times lower than the A. niger and Penicillium frequentans polygalacturonases, respectively using the same substrate [23]. This indicates that the current exopolygalacturonase has a higher affinity for PGA compared to the other two. Similarly, the current exo-polygalacturonase had 1.38, 1.47 and 1.65 times more affinity towards PGA substrate than the commercial enzymes Rapidase C80, Pectinase CCM and Pectinex, respectively jugged from the $K_{\mathrm{m}}$ values [27]. $V_{\mathrm{m}}$ which is an indication of the catalytic activity of an enzyme is usually desired to be as high as possible, therefore the cur-
Table 3

Effect of metal ions on the activity of the purified exo-polygalacturonase enzyme

\begin{tabular}{lll}
\hline \multicolumn{3}{c}{ \% Relative activity } \\
\hline Control & \multicolumn{1}{l}{100} \\
Metal ions (mM) & 1 & 10 \\
$\mathrm{KCl}$ & $174.81 \pm 3.95$ & $94.35 \pm 0.91$ \\
$\mathrm{NaCl}$ & $124.57 \pm 3.67$ & $84.75 \pm 3.19$ \\
$\mathrm{CaCl}$ & $116.00 \pm 2.58$ & $101.25 \pm 3.26$ \\
$\mathrm{MgCl}_{2}$ & $93.51 \pm 4.01$ & $93.42 \pm 3.93$ \\
$\mathrm{MnCl}_{2}$ & $0 \pm 0$ & $0 \pm 0$ \\
$\mathrm{ZnCl}_{2}$ & $99.94 \pm 1.12$ & $112.79 \pm 1.83$ \\
$\mathrm{CuSO}_{4}$ & $55.47 \pm 2.07$ & $42.67 \pm 3.17$ \\
$\mathrm{FeSO}_{4}$ & $74.58 \pm 2.20$ & $97.66 \pm 1.10$ \\
\hline
\end{tabular}

Activity without added metal ions was taken as $100 \%$ activity.

rent value obtained in this study was very comparable to many studies in the literature $[27,30]$.

\subsection{Effect of metal ions and various compounds on exo-polygalacturonase activity}

The effects of metal ions were examined by adding the chlorides of $\mathrm{K}^{+}, \mathrm{Na}^{+}, \mathrm{Ca}^{2+}, \mathrm{Mg}^{2+}, \mathrm{Mn}^{2+}$ and $\mathrm{Zn}^{2+}$ and the sulphates of $\mathrm{Cu}^{2+}$ and $\mathrm{Fe}^{2+}$ at different concentrations to the buffer solution. As it can be observed from Table 3, the enzyme was induced in the presence of $1 \mathrm{mM}$ of $\mathrm{K}^{+}, \mathrm{Na}^{+}, \mathrm{Ca}^{2+}$ ions, and completely inhibited in the presence of $\mathrm{Mn}^{2+}$ at both concentrations studied. Furthermore at $1 \mathrm{mM}$ concentration, $\mathrm{Cu}^{2+}$ and $\mathrm{Fe}^{2+}$ reduced the enzyme activity where $\mathrm{Zn}^{2+}$ did not have any profound effect. The effect of these ions were concentration dependent. For example increasing the concentration of $\mathrm{K}^{+}, \mathrm{Na}^{+}$, and $\mathrm{Ca}^{2+}$ from 1 to $10 \mathrm{mM}$, reduced the enzyme activity by $1.85-, 1.47-$ and 1.15-fold, respectively. Similarly, increasing the concentration of $\mathrm{Mg}^{2+}, \mathrm{Zn}^{2+}, \mathrm{Cu}^{2+}$ and $\mathrm{Fe}^{2+}$ to $10 \mathrm{mM}$, resulted in no change in exo-polygalacturonase activity for $\mathrm{Mg}^{2+}$, a 1.3-fold reduction for $\mathrm{Cu}^{2+}$ and 1.12- and 1.31-fold of increase for $\mathrm{Zn}^{2+}$ and $\mathrm{Fe}^{2+}$, respectively. In various studies reported in the literature different results were obtained depending on the ion used and the source of the exo-polygalacturonase [31,24]. For example in a study conducted by Kaur et al. [26], it was reported that the activity of pectinase was stimulated by $\mathrm{Fe}^{2+}$ and $\mathrm{Mn}^{2+}$ at both $1 \mathrm{mM}$ and $5 \mathrm{mM}$ and inhibited strongly at $5 \mathrm{mM}$ by $\mathrm{Mg}^{2+}$. These results were partly in agreement with our results. Similarly, the current results were comparable to a study conducted by Mohamed et al. [30]. Overall these results revealed that the exo-polygalacturonase activity does not necessarily depend on the metal ion except for $\mathrm{Mn}^{2+}$ and $\mathrm{Cu}^{2+}$, which inhibit and significantly reduce the activity. The effect of metal ions which are concentration dependent could be important, where media formulations are prepared with raw materials of high salt content.

Various compounds such as listed in Table 4 in different concentrations were examined in order to determine their effect on the exo-polygalacturonase activity. ETDA as chealating agent had promoting effect proportional with concentration in the range of $1-10 \mathrm{mM}$. This finding was reconfirming that exo-polygalacturonase does not strongly depend on metal ions as discussed above, which otherwise would have been inhib- 
Table 4

Effect of different compounds on the activity of the purified exopolygalacturonase enzyme

\begin{tabular}{llc}
\hline Compounds & Concentration $(\mathrm{mM})$ & \% Relative activity \\
\hline EDTA & 1 & $132.98 \pm 1.25$ \\
& 5 & $165.03 \pm 1.43$ \\
& 10 & $195.26 \pm 0.53$ \\
Glycerol & 1 & $111.66 \pm 1.06$ \\
& 5 & $233.58 \pm 1.89$ \\
Tween 80 & 10 & $283.76 \pm 1.68$ \\
SDS & $(0.02 \%)$ & $96.41 \pm 1.97$ \\
$\beta$-Mercaptoethanol & $(0.1 \%)$ & $0 \pm 0$ \\
\hline
\end{tabular}

The activity without added compound was taken as 100\% activity. EDTA: ethylenediaminetetraacetic acid; SDS: sodium dodecyl sulphate.

ited in the presence of EDTA. Similarly, glycerol which is mostly used as protective agent in preservation promoted exopolygalacturonase activity significantly with an increase in the concentration from 1 to $10 \mathrm{mM}$. Therefore, glycerol can be recommended for preservation of exo-polygalacturonase enzyme during storage. Tween 80 known as surface-active agent and very popular in the fermentation media formulations, slightly inhibited the enzyme activity at a concentration of $0.02 \%$. SDS a protein denaturant, inhibited enzyme activity of the exopolygalacturonase completely, whereas $\beta$-mercarptoethanol increased the enzyme activity by 3.63 -fold compared to control suggesting that disulphide linkages do not have a critical role in maintaining an appropriate conformation of the enzyme for its catalytic activity. This finding was partly in agreement with the study conducted by Kaur et al. [26] who determined inhibitory effect of both SDS and $\beta$-mercarptoethanol on thermostable exo-polygalacturonase from $S$. thermophile Apinis.

SDS-PAGE analysis of the purified enzyme revealed two single bands with the molecular weights of 36 and $53 \mathrm{kDa}$, indicating either the presence of two isozymes of exopolygalacturonase, or the sub-units of a single polygalacturonase or other impurities. This needs to be exploited further in future. Two different exo-polygalacturonases with different molecular weights such as 38 and $61 \mathrm{kDa} ; 38$ and $65 \mathrm{kDa} ; 63$ and $79 \mathrm{kDa}$ were reported for A. niger, A. japonicus and P. frequentans, respectively [3]. Similar, result of two isoforms with the molecular weights of 46 and $47 \mathrm{kDa}$ of pectinesterase was obtained by a study conducted by Hasanuma et al. [32]. Therefore, the current enzyme will be a new example in the literature with this respect.

\section{Conclusion}

After characterization of the exo-polygalacturonase purified with an emerging bio-separation technique TTP, it was concluded that this enzyme could be a candidate with potential applications primary in food, waste treatment centers, paper and textile industries. As a exo-polygalacturonase from a new strain (A. sojae), which was not considered for this purpose so far, will be a new reference point for the enzyme industry and microbiology area and will fill the gap in the literature. As it is known discovering new enzymes with novel properties is a tedious and difficult task to perform, therefore enzymes from new sources with unique properties such as the one here may have an enormous economic significance which should not be overlooked.

\section{Acknowledgement}

Financial support of Izmir Institute of Technology are gratefully acknowledged.

\section{References}

[1] K. Saito, N. Takakuwa, Y. Oda, Purification of the extracellular pectinolytic enzyme from the fungus Rhizopus oryzae NBRC 4707, Microbiol. Res. 159 (2004) 83-86.

[2] G.S. Hoondal, R.P. Tiwari, T. Tiwari, N. Dahiya, Q.K. Beg, Microbial alkaline pectinases and their applications: a review, Appl. Microbiol. Biotechnol. 59 (2002) 409-418.

[3] R.S. Jayani, S. Saxena, R. Gupta, Microbial pectinolytic enzymes: a review, Process Biochem. 40 (9) (2005) 2931-2944.

[4] D.R. Kashyap, P.K. Vohra, S. Chopra, R. Tewari, Applications of pectinases in the commercial sector: a review, Bioresour. Technol. 77 (2001) 215-227.

[5] S.N. Gummadi, T. Panda, Purification and biochemical properties of microbial pectinases-a review, Process Biochem. 38 (2003) 987-996.

[6] A. Sharma, M.N. Gupta, Purification of pectinases by three-phase partitioning, Biotechnol. Lett. 23 (2001) 1625-1627.

[7] S. Kansal, A. Sharma, M.N. Gupta, An integrated process for obtaining oil, protease inhibitors and lectin from soybean flour, Food Res. Int. 39 (2006) 499-502.

[8] I. Roy, M.N. Gupta, Three-phase partitioning of proteins, Anal. Biochem. 300 (2002) 11-14.

[9] F.I. Ustok, C. Tari, N. Gogus, Solid-state production of polygalacturonase by Aspergillus sojae ATCC 20235, J. Biotechnol. 127 (2007) 322-334.

[10] C. Tari, N. Gogus, F. Tokatli, Optimization of biomass, pellet size and polygalacturonase production by Aspergiluus sojae ATCC 20235 using response surface methodology, Enzyme Microbiol. Technol. 40 (2007) $1108-1116$

[11] N. Gogus, C. Tari, S. Oncü, S. Unluturk, F. Tokatli, Investigation of the relationship morphology, rheology and polygalacturonase production by Aspergillus sojae 20235 in submerged cultures, Biochem. Eng. J. 32 (2006) 171-178.

[12] T. Panda, G.S.N. Naidu, J. Sinha, Multiresponse analysis of microbiological parameters affecting the production of pectolytic enzymes by Aspergillus niger: a statistical view, Process Biochem. 35 (1999) 187-195.

[13] O.H. Lowry, N.J. Rosebrough, A.L. Farr, J.R. Randall, Protein measurement with the folin phenol reagent, J. Biol. Chem. 193 (1951) 265-275.

[14] U.K. Laemmli, Cleavage of structure proteins during the assembly of the head of bacteriophaage T4, Nature 227 (1970) 680-685.

[15] R.M. Atlas, A.E. Brown, L.C. Parks, Experimental Microbiology, Laboratory Manual, Mosby-Year, 1995, pp. 545-548.

[16] M.L. Shuler, F. Kargi, Bioprocess Engineering Basic Concepts, 2nd ed., Prentice Hall, 2002, pp. 77-78.

[17] S. Shah, S. Sharma, M.N. Gupta, Extraction of oil from Jatropha curcas L. seed kernels by enzyme assisted three-phase partitioning, Ind. Crop Prod. 20 (2004) 275-279.

[18] C. Dennison, R. Lovrien, Three-phase partitioning: concentration and purification of proteins, Protein Expres. Purif. 11 (1997) 149-161.

[19] S. Sharma, M.N. Gupta, Purification of phospholipase D from Dacus carota by three-phase partitioning and its characterization, Protein Expres. Purif. 21 (2001) 310-316.

[20] A. Sharma, K. Mondal, M.N. Gupta, Some studies on characterization of three phase partitioned chitosan, Carbohyd. Polym. 52 (2003) 433-438.

[21] I. Roy, A. Sharma, M.N. Gupta, Recovery of biological activity in reversibly inactivated proteins by three-phase partitioning, Enzyme Microbiol. Technol. 37 (2005) 113-120. 
[22] T. Sakamoto, E. Bonnin, B. Quemener, J.F. Thibault, Purification and characterization of two exo-polygalacturonases from Aspergillus niger able to degrade xylogalacturonan and acetylated homogalcturonan, Biochem. Biophys. Acta 1572 (2002) 10-18.

[23] J.P.R. Keon, G. Waksman, Common amino acid domain among endopolygalacturonases of Ascomycete fungi, Appl. Environ. Microbiol. (1990) 2522-2528.

[24] C. Riou, G. Freyssinet, M. Fevre, Purification and characterization of extracellular pectinolytic enzymes produced by Sclerotinia sclerotiorum, Appl. Environ. Microbiol. (1992) 578-583.

[25] I. Roy, M.N. Gupta, Enhancing reaction rate for transesterification reaction catalyzed by Chromobacterium lipase, Enzyme Microbiol. Technol. 36 (2005) 896-899.

[26] G. Kaur, S. Kumar, T. Satyanaraya, Production and characterization and application of a thermostable polygalacturonase of a thermophilic mould Sporotrichum thermophile Apinis, Bioresour. Technol. 94 (2004) 239-243.
[27] N. Ortega, S. de Diego, M. Perez-Mateos, M.D. Busto, Kinetic properties and thermal behavior of polygalacturonase used in fruit juice clarification, Food Chem. 88 (2004) 209-217.

[28] H.N. Bhatti, M. Asgher, A. Abbas, R. Nawaz, M.A. Sheikh, Studies on kinetics and thermostability of a novel acid invertase from Fusarium solani, J. Agric. Food Chem. 54 (2006) 4617-4623.

[29] G.S. Naidu, T. Panda, Studies on $\mathrm{pH}$ and thermal inactivation of pectolytic enzymes from Aspergillus niger, Biochem. Eng. J. 16 (2003) 57-67.

[30] S.A. Mohamed, N.M. Farid, E.N. Hossiny, R.I. Bassuiny, Biochemical characterization of an extracellular polygalacturonase from Trichoderma harzianum, J. Biotechnol. 127 (2006) 54-64.

[31] M. Kapoor, Q.K. Beg, B. Bhushan, K.S. Dadhich, G.S. Hoondal, Production and partial purification of a thermo alkali stable polygalacturonase from Bacillus sp. MG-cp-2, Process Biochem. 36 (2000) 467-473.

[32] T. Hasanuma, E.I. Fukusaki, A. Kobayashi, Methanol production is enhanced by expression of an Aspergillus niger pectin methlyesterase in tobacco cells, J. Biotechnol. 106 (2003) 45-52. 